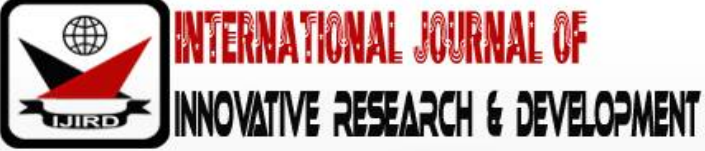

ISSN 2278 - 0211 (Online)

\section{Examining the Recruitment and Selection Challenges Faced by Higher Educational Institutions in Ghana: Evidence from Takoradii Technical University}

Daniel Odoom
Research Coordinator, Ghana Technology University College, Takoradi Campus, Ghana
Samuel K. Amegatsey
MPhil Scholar, Institute of Educational Planning and Administration, University of Cape Coast, Ghana
Bernard Arpoh-Baah
Lecturer, Ghana Technology University College, Takoradi Campus, Ghana
Isaac Okyere
Assistant Lecturer, Ghana Technology University College, Koforidua Campus, Ghana

\begin{abstract}
:
This study examined the recruitment and selection challenges faced by higher educational institutions in Ghana with using Takoradi Technical University (TTU) as a case. The convergent parallel mixed method research approach was adopted in a descriptive survey design. A total of 94 respondents made up of 92 teaching staff and two key officers of the University were involved in the study using stratified, simple random and purposive sampling techniques, with questionnaire and interview guide as the instruments for data collection. Statistical tools such as frequencies, percentages and independent sample t-test were used for analyzing the quantitative data, whilst in the case of the qualitative analysis, transcribed data were analyzed thematically. The study observed that low salary and inadequate incentive packages in the institution, insufficient autonomy, competition from other tertiary institutions, and favoritism and personal contact were challenges to recruitment and selection. Other challenges found include over-reliance on internal recruitment, delays in declaring vacant positions, and political influence. These challenges were problematic to the success of recruitment and selection process of the University. Also, the recruitment and selection challenges that male lecturers faced were not different from that of their female colleagues. It is recommended that government should facilitate the employment of persons to teach in the tertiary institutions by way of removing embargos and providing the necessary clearance to enable the institution address its human resource capacity gaps. The Management of Takoradi Technical University should team up with the HRM Division to come out with clear measures to enhance transparency in recruitment and selection process.
\end{abstract}

Keywords: Human resource management, tertiary institutions, recruitment, technical university

\section{Introduction}

In today's globalized and information-based society, human resource remains the most vital ingredient to drive organizational success. As companies and institutions re-organize to gain competitive edge, human resources still play key roles in helping companies and institutions to deal with the fast-changing competitive environment and greater demand for quality employees. The survival of every organization rests very much on its ability to attract and retain qualified workers (Rebore, 2001).Human resource can be viewed as the sum total or aggregate of inherent abilities, acquired knowledge and skills represented by talents and aptitudes of the persons employed in an organization (Sudhir, 2001). Similarly, Harbison (1973) expressed that human resources constitute the energies, skills, talents and knowledge of people which are, or which potentially can or should be applied to the production of goods or the rendering of useful services. Harbison further asserted that human resources embrace as well the thoughts, motives, believes, feelings, aspirations, and the culture of human beings beyond and outside of work. According to Odoom, Opoku and Ayipah (2016a), the effectiveness and success of any organization depends on the people who form and work within that organization. The authors add that for employees in an institution to perform their duties and make meaningful contributions to the success of the organizational goals, they need to acquire the requisite skills and knowledge about their work. Importantly, at the national level, it is human resources of nations, not their capital nor material resources that ultimately determine the character and pace of their economic and social development (Odoom, Opoku and Ayipah, 2017).

Tertiary institutions all over the world are established to help address the human resource needs confronting various nations. They provide advance academic and or professional instruction and conduct research in the sciences, social sciences, humanities and engineering programs (National Accreditation Board Report, 2008). In fact, tertiary institutions in Ghana are not different from their counterparts in other nations in terms of their mandate. As part of 
making themselves continuously relevant, tertiary institutions have gone through some changes over the past years and the polytechnics and technical universities have not been an exception (Carol, 2008).

In 1987, the Government of Ghana set up a University Rationalization Committee (URC) to develop proposals for reforming the management, academic structure and funding of tertiary education in Ghana. Following the submission of the URC's report, the government issued a white paper in 1991 on the Reforms to the Tertiary Education System (Nyarko, 2011). This reform led to the upgrading of the polytechnics to Diploma and Higher National Diploma awarding institutions. Also, in recent times some of the polytechnics including Takoradi. Poly were upgraded and mandated to award degree programs. It is believed that if the polytechnics are to perform their duties as efficiently as possible and to manage change effectively, there is the need to consider the human resources available that ought to accompany the change in status (Honyenuga, 2013). Nyarko (2011) shared similar position with Honyenuga (2013). Nyarko also, indicated that in order for the changes in polytechnics, of which T-Poly is part, to fully occur there is the need for requisite human resources capacity. The collective performance of the entire workforce will firmly position the institution to attain its desired goals and thereby remain one of the strong technical educational institutions in the country. It is against this background that this study sought to examine the human resource challenges at Takoradi Technical University.

The human resource challenges facing the various polytechnics, and now technical universities (for some) in Ghana is also highlighted by The Report of the Technical Committee on Conversion of Polytechnics in Ghana to Technical Universities (2014). The Report of the Technical Committee on Conversion of Polytechnics in Ghana to Technical Universities (2014, p.6) made it clear that "by far, the greatest challenge facing the polytechnics is their ability to recruit and retain qualified staff with relevant practical or professional experience". The report attributed this to the fact that the type of skilled professionals that the polytechnics require is also those highly sought after by industrial establishments.

Over the past two decades, Takoradi Technical University like any other Technical University in the country has experienced a lot of advancement in its mandate, thus growing from a technical institute into a tertiary level institution. This was as a result of the enactment of the PNDC Law 321 which gave legal backing to the upgrading of the institution, alongside other polytechnics into tertiary institutions to offer Higher National Diploma (HND) programs. The Polytechnic Law (Act 745) has also mandated the Polytechnic to run degree programs. In view of this, some schools including the School of Engineering started a Bachelor of Technology Degree Program in Building Technology in 2008/ 2009 academic year upon an accreditation received from the National Accreditation Board (NAB). In 2016, eight out of the ten polytechnics were further converted into technical universities through the passage of Technical Universities Bill into law. The technical universities were mandated to be in charge of industrial human resource training for the country with their main aim being not to deviate from what makes them unique from the mainstream universities. In fact, given the new status as a technical university to run diploma, degree and postgraduate programs, one would expect a corresponding change in the institution's human resource base. However, no evidence exists to the extent that these institutions have the requisite HR capacity to be able to deliver their core mandate successfully. This situation is problematic in the face of the expectations of scholars including Nyarko (2011) and Honyenuga (2013). These scholars maintain that polytechnics and for that matter tertiary institutions of the nation cannot grow and develop without the requisite HR capacity. This study therefore sought to examine the recruitment challenges faced by tertiary institutions in Ghana using Takoradi Technical University as a case in order to suggest measures for improvement.

\subsection{Research Aim}

The aim of this study was to examine the recruitment challenges facing Takoradi Technical University.

\subsection{Research Objectives}

- To explore the challenges faced by Takoradi Technical University in the recruitment of academic staff.

- Determine whether or not there is any difference between the views of male and female lecturers regarding recruitment and selection challenges at TTU.

\subsection{Research Hypotheses}

- $\mathrm{H}_{0}$ : There is no statistically significant difference in recruitment and selection challenges according to the gender of lecturers.

- $\mathrm{H}_{1}$ : There is a statistically significant difference in the recruitment and selection challenges according to the gender of lecturers.

\section{Literature Review}

\subsection{Human Resource Management Practices and Employee Retention}

Practices or programs that contribute to employee retention arise in all areas of human resource. When the program is working well, employees will be generally satisfied with their employment. The satisfaction leads them to be willing to act in the best interest of the organization rather than solely their own best interests. Retention strategies should be viewed by top management as part of their responsibility considering that the long-term loyalty of highly skilled employees to an organization is no longer the norm in the face of the high mobility rate of skilled employees. Managements of organizations are therefore faced with the most important challenge of implementing multifaceted retention strategies to hold on to their competent employees (Armstrong, 2006). The HRM practices that are implemented to ensure retention of valued staff include the following: human resource planning, effective recruitment drive, training and career development, remuneration and motivation, among others. 


\subsection{Human Resource Planning}

Planning is very essential in all endeavors of human life. As such, planning of human resource cannot be overemphasized. To affirm this viewpoint, Rebore (1982) asserted that planning is a process common to all human experience. Before one embarks on a journey, an individual must understand where he is, know where he wants to go and decides how best to get there. This in a simple form, typifies the need for a process even as it is applied to educational organizations. Through the process of human resource planning a school is able to get the right number of people, with the right skills at the right place, and at the right time and that these people are capable of effectively carrying out those tasks that will aid the organization in achieving its objectives (Rebore, 1982). For any organization, and for that matter a school to achieve its objectives, it needs financial, physical and human resources. An organization that does not plan for its human resources will often find that it is not meeting either, its personnel requirements or its overall goals effectively. Thus, effective HRM must start at the planning stage of the institution.

According to Rebore (1982), staffs who are one of the elements of an organization's resources, are taken for granted, and yet they are the force that directly affects the main objective of a school - to educate children. In some school districts, long and short-range objectives are couched in ambiguous language and often known to central office administrators only. This makes it really difficult to involve building principals in the hiring process when unexpected vacancies occur, when replacements are needed because of natural attrition, or when new programs must be staffed. Rebore (1982) saw workforce planning as a process that ensures the smooth development of an organization. In this regard, Rebore further expressed that to ensure effective human resource in any organization, there is the need to assess where the organization is; where it is going; the implications of these objectives on future demands and future supply of human resources; and attempts to match demand and supply so as to make them compatible with the achievement of the organization's future needs. Cole (1996) likened human resource planning to any other form of planning and emphasized the fact that it is a means to an end. In this case, the end is to secure adequate human resources in order to achieve corporate objectives.

In furtherance, Cole (1996) asserts that organizations which have adopted corporate planning or strategic approach to human resource planning (planning of labor pool) need to do an overall assessment of the current strengths and weaknesses of the employee situation. This assessment will have led, where necessary, to a number of long-term proposals for human resources planning aimed at securing sufficient numbers and categories of suitable employees to undertake the task of producing the organization's goods or services to the standards expected by the end-users. Even organizations that rarely plan far ahead usually have to make some assessment of their present employee situation so as to ensure that an appropriate range of skills is available for all the mainstream activities of the organization. To this end, Cole assumed that a systematic and planned view of human resource planning is the norm. Adesina (1990), in discussing the goals of personnel administration in a school system stated that the overall goal of the personnel administration is to recruit adequate and qualified staff, develop and maintain the staff so that they would be able and willing to render effective and efficient educational services to the students. It should be noted that the statement took into consideration the qualitative and quantitative aspects of the staff required. The staff must be adequate in terms of size and professionally qualified to face the tasks set for them in the school system. He emphasized the fact that the premises upon which a personnel plan can be classified are internal, and external.

Internal premises relate to those conditions within the school system, which would influence the school's personnel plan. Examples of these are: student enrolment, financial solvency or indebtedness of the school, the conditions of physical facilities available and so on which can pose as constraints or promoters of a school's personnel plan. External premises would see such realities like shortage or oversupply of staff required in the job market and political and governmental intervention and control, population trends and government fiscal policy (Adesina, 1990). In deepening the above position, Rebore (1982) suggests that within the school system, manpower planning is sometimes understood only within the confines of the instructional programs. However, for every teacher there is usually a support employee. This is because a contemporary school district employs not only teachers and administrators but also cooks custodians, maintenance personnel, secretaries, computer programmers, drivers and accountants who are often thought to be employed only by private business sector by the average citizen. To this end, organizations' strategies and the external environment sought to broadly define the limits within which the human resource plan must operate. Forecasting and human resource audits can then determine more specific human resource needs in order for appropriate measures to be taken.

\subsection{Recruitment and Selection}

In attracting employees into an organization the starting point is recruitment. Recruitment attracts a pool of prospective employees into an organization for selection to be done. Several authorities have expressed their views on the concept of recruitment. Bratton and Gold (2007) noted that recruitment is the process of generating a pool of capable people to apply for employment to an organisation. In the opinion of Noe (2004), recruitment is the process through which the organisation seeks applicants for potential employment. It is thus, the seeking for and obtaining potential job candidates. It is striking to note that Bratton and Gold as well as Noe have all perceived recruitment as a process as clearly stated in their respective definitions of recruitment. Furthermore, Harris (2009) viewed recruitment as the first part of the process of filling a vacancy. It includes the examination of the vacancy, the consideration of sources of suitable candidates, making contact with those candidates and attracting the best ones from them.

The position of Harris (2009) was corroborated by Gerber, Nel and Van Dyk (1998). On their part, Gerber et al., defined recruitment as those organizational activities that influence the number and or/ types of applicants who apply for a position and/or affect whether a job offer is accepted. As a process, recruitment also entails discovering potential 
applicants for anticipated vacancies. This view on recruitment process depends, to a large extent, on size of an organization. This is because enterprises which are large have higher tendency of recruiting potential applicants than the smaller organizations which are usually located far from urban centers. Recruitment is a two-dimensional affair/ process in the sense that just as organizations are searching for potential applicants; the applicants themselves are also searching for suitable organizations for employment. Rebore (2007) believed that the principal purpose of recruitment activities is to attract sufficient and suitable potential employees to apply for vacancies in the organization.Selection happens to be the next most important stage in the hiring process. Cole (2004) indicated that the task of selection is to cream off the most appropriate applicants, turn them into candidates, and persuade them that it is in their interest to join the organization, Selection is very much a two-way process, that is the candidate is assessing the organization, just as much as the organization is assessing the candidate.

Acheampong (2006) believed that selection is the process of matching prospective employees to the jobs they have applied for. Acheampong noted that the selection process is very crucial in human resource development because if the task of employee-job-fit is not achieved then both the organization and the individual worker would suffer. In the perspective of Analoui (2007), selection is a process of choosing from among available applicants the individuals who are likely to successfully perform a job. Similarly, Gomez-Mejia, Balkin and Cardy (2007) stated that selection is a process of making a 'hire' or 'no hire decision regarding each applicant for a job. The process typically involves determining the characteristics required for effective job performance and then measuring applicants on those characteristics, which are typically based on the job analysis. In a related vein, Bratton and Gold (2007) saw selection as the process by which managers and others use specific instruments to choose from a pool of applicants a person or persons more likely to succeed in the job(s), given management goals and legal requirements. The major selection methods include interviews, assessment centers, and various written tests such as achievement tests, aptitude tests, and personality tests. However, amongst all the selection methods, the interview is by far the most commonly used in many institutions of higher learning. Interviews in their own right can take several forms which include the structured interview, the unstructured interview, the board or panel interview, and the group interview.

Recruitment and selection are two processes which are inextricable in HRM Practices. Recruitment and selection have an important role to play in ensuring worker performance and positive organisational outcomes. It is often claimed that selection of workers occurs not just to replace departing employees or add to a workforce but rather aims to put in place workers who can perform at a high level and demonstrate commitment (Ballantyne, 2009).Effective recruitment and selection can play a pivotal role in shaping an organisation's effectiveness and performance, if organisations are able to acquire workers who already possess relevant knowledge, skills and aptitudes and are also able to make an accurate prediction regarding their future abilities. If we accept this premise, then recruiting and selecting staff in an effective manner can both avoid undesirable costs - for example those associated with high staff turnover, poor performance and dissatisfied customers - and engender a mutually beneficial employment relationship characterised, wherever possible, by high commitment on both sides.

\subsection{Challenges Associated with Recruitment}

Several challenges and constraints exist in employee recruitment and HR practices. One of the major constraints as posited by Rebore (2007) in recruiting for a position centers around the attractiveness of the job itself. A position that is viewed as anxiety laden and lacks promotion potentials may not command appreciable interest of the best brains. People especially skilled workers do not accept job offer to any position. They usually consider the implications and the opportunities associated with the job offer. In essence, when potential workers realize that the vacant position has less to offer them in their professional career and life in general, they do turn down the offer.

Another challenge has to do with salary and fringe benefits. Rebore (2007) argued that the best people for a job will become candidates if the financial compensation is in keeping with the responsibilities of the position. Education is a service enterprise and, as such, the major priority must be attracting the highly qualified employees. Recruiters may need to negotiate compensation with individuals or interested job candidates. This practice, in the viewpoint of Rebore helps to attract highly qualified individuals for less desirable positions. In school districts the salary for a position is usually fixed on a salary schedule and the fringe benefits are universally applied to all employees in a certain category. This makes the recruitment of highly qualified candidates a very difficult task especially if the position to be filled is the undesirable one. Besides, if the salary and the fringe benefits are not motivating enough, recruiters may find it a herculean task to fill certain positions.

Low salary is a major challenge to recruitment and selection. It has been revealed that salary levels in sectors such as energy, finance, revenue collection, and the media are all higher than those of the tertiary institutions (Adesina, 1990; Effah, 2006; Kwaw, 2015; Teferra \& Altbach, 2004). Nyarko (2011) argues that the conditions of service and incentives such as provision of medical care, accommodation and sponsorship for further studies offered to employees in polytechnics have not been as attractive when compared to similar institutions. This militates against the attraction and retention of qualified staff. Thus, inadequate incentives challenge the success of recruitment and selection in tertiary institutions. For some employees, incentives designed to motivate them may actually demotivate them if they seem to be unfair or too difficult to obtain. Additionally, incentives can sometimes cause unhealthy competition among employees and either force employees to cut corners or sabotage their colleagues (Beauregard and Fitzgerald, 2000; Kwaw, 2015).

More so, there are government restrictions which pose a huge challenge to recruitment and selection. In the opinion of Gerber et al. (1998), government legislation and regulations must be taken into consideration when a recruitment program is being planned. In many countries, since the government is the single largest employer, government directives such as quotas and embargos on recruitment serve as great barriers to public institutions to 
employ new workers. Currently in Ghana, there is a freeze on public sector employment and this phenomenon has worsened the economic conditions of several graduates who are constantly searching for public sector engagement. This has led to insufficient autonomy to carry out HR operations such as recruitment and selection in the institution. Whit church and Gordon (2007) assert that there is a simplified dichotomy between tertiary institutions which have power and responsibility as employers of staff and institutions where this authority rests with the government. In the former, the institution can, for instance, appoint, grade and, at least to a degree, determine the reward of staff, aspects of their conditions of employment, their development, and the building of capacity.

Another challenge associated with recruitment and selection is unrealistic expectations coupled with general lack of knowledge that many job applicants have about the job at the time that they receive an offer (De Boer et al., 2002). There are often unrealistic expectations from employees in terms of job content, job-related problems, and work tasks. When these unrealistic expectations are not realized, the worker becomes disappointed and dissatisfied which may force the employee to decide to quit the job. Thus, employers are often challenged by the general lack of knowledge and unrealistic expectations of applicants.

Again, there is the issue of competition from other knowledge providers or businesses for highly qualified professional within the same country (Teferra \& Altbach, 2004). Afeti (2003) opines that the very qualified staffs needed in the polytechnics are those who are greatly sought after by other institutions. In support, Gascard (2012) and Kwaw (2015) maintain that such competition often hits fields such as medicine, technology and engineering, where tertiary institutions fail to compete with each other and the private sector due to several factors including salary differentiation.

There is also the issue of over-reliance on internal recruitment including promoting the already working staff to occupy vacant positions deserves attention. In the view of Rebore (2007), this practice has clear advantage in creating high morale among employees. Teaching assistants could be promoted into full- time lecturers when vacancies are available. Similarly, most tertiary institutions have classroom teachers qualified to become principals, deans, and heads of department which they tend to rely on during recruitment and selection of applicant for such positions. The danger, however, is that the situation may lead to inbreeding and also denial of more qualified personnel.

\section{Research Methodology}

The study employed the mixed methods approach with particular focus on convergent parallel mixed methods design. The convergent parallel mixed methods design, in the views of Plano Clark and Creswell (2015), is a set of procedures that researchers use to concurrently collect both quantitative and qualitative data, analyze the two data sets separately, compare and/ or synthesize the two sets of separate results, and make an overall interpretation as to the extent to which the separate results confirm and or complement each other. The convergent parallel mixed methods design is considered most appropriate for the study because it has usefulness for both quantitative and qualitative approaches. Moreover, a good application of the convergent parallel design, assists researchers to carefully combine the quantitative and qualitative data forms to develop results and conclusions about the topic that are more complete and/ or more valid. More complete results are obtained when the researchers use the different methods to examine different facets of as study's topic. More valid results are established within a convergent parallel design when researchers corroborate and disagree on results from both quantitative and qualitative information. Similarly, by comparing quantitative and qualitative results, this design can also discover inconsistencies in the results when the quantitative and qualitative information do not agree. Some researchers view such a disagreement as troubling. However, Plano Clark and Creswell (2015) argued that some researchers see the disagreement as an ideal opportunity to learn even more about the phenomenon by examining why the inconsistent results emerged. The target population mainly was the teaching staff of Takoradi Technical University. However, two principal administrators (the Registrar and Human Resource Manager) of the institution were considered in the study due to the critical roles their outfits play in the management of human resources issues at the institution. In order to increase the validity of the data for the study, the stratified sampling that incorporates elements of simple random sampling was adopted for selecting the teaching staff of the various schools in the institution. Available record at the human resources division of Takoradi Technical University put the total faculty size at 305. Out of this faculty population, 94 (two deans and 92 lecturers) were involved in the study. This represents 30.81 percent of the total teaching staff population. According to Nwana (1992), if a researcher in a study is dealing with a few hundred people as the population, 30- 40 percent of the population will be representative enough. The instruments used for data collection are questionnaire and interview guide. These two instruments were used to overcome the weaknesses or deficiencies of either the questionnaire or the interview guide and to create a balance by ensuring that the particular biases and flaws associated with a single data gathering instrument are counteracted. Data was analysed using both quantitative and qualitative methods. For instance, statistical tools such as frequencies, percentages and independent sample t-test were used for analyzing the quantitative data, whilst in the case of the qualitative analysis, transcribed data were analyzed thematically.

\section{Results and Discussion}

The first aspect of the presentation was on the background information of respondents in the study while the second part presented the main results from the questionnaire and testing of the hypotheses. The final part dealt with the transcribed data, followed by the discussion and comparing or merging of the results according to the research questions. Table 1 presented the background information of participants in the study with the majority being males (62\%). This helped to ascertain the views of males and female respondents on the human resource challenges at Takoradi Technical University. Luddy, as cited in Odoom, Opoku and Ayipah (2016), opines that sex distribution of employees influences their perceptions on HRM practices. In their study, Murray and Atkinson, as cited in Kwaw (2015) established that females 
attach much attention to social factors, while males placed greater importance on pay, advancement and other extrinsic aspects. Moreover, a greater percentage of the participants (94\%) were also found to have master's degree as their highest educational qualification. Participants again indicated having worked for considerable number of years as senior members in Takoradi Technical University, with majority of them (70\%) having worked for 6 to 10 years in the institution.

\begin{tabular}{|c|c|c|}
\hline Demographic & $\begin{array}{c}\text { Frequency } \\
\text { (n=92) }\end{array}$ & $\begin{array}{c}\text { Percentage } \\
\mathbf{( 1 0 0 \% )}\end{array}$ \\
\hline Sex of Respondents & 57 & 62.0 \\
Male & 35 & 38.0 \\
Female & 0 & \\
PhD & 86 & 93.5 \\
Masters' degree & 6 & 6.5 \\
\hline First degree & 6 & \\
Years of Work & 13 & 6.5 \\
Less than 1 year & 64 & 14.1 \\
1 - 5 years & 3 & 69.6 \\
6 - 10 years & 6 & 3.3 \\
11 - 15 years & 6.5 \\
\hline More than 15 years & \\
\hline Tabs Educational Qualification
\end{tabular}

Table 1: Background Information of Participants Source: Field Survey, 2016

The focus of the first research objective was to ascertain the various challenges that hinder the efforts of the authorities of Takoradi Technical University in their recruitment drive. The result on each item of the questionnaire is presented followed by the results from the interview guide. In other words, after each item is presented quantitatively, the qualitative result is used to either confirm or dispute the quantitative one. Again, in analyzing the quantitative data, the responses for the Strongly Agree and Agree were collapsed into one whilst the responses for the Strongly Disagree and Disagree were collapsed into one. The challenges as indicated by participants in the questionnaire are presented in Table 2 , showing respondents' level of agreement and disagreement on the challenges to recruitment and selection in the Takoradi Technical University.

The first recruitment challenge is poor salary in the University as compared with other tertiary institutions. From Table 2, it is obvious that 88.1 percent of the respondents believed that their salary was low compared with what their colleagues with similar qualifications in other public universities are earning. However, 11.9 percent generally opposed the above view. By implication, most of the respondents believed as a result of low salary compared with what pertains in other settings, many well-qualified personnel are not attracted to the institution. During the interview, the key informants generally debunked the notion that salary level was low. In the words of one informant, "Lecturers of Technical Universities are among the well paid workers in Ghana. It cannot be true that salary is low. Go to the public universities and you will see that the situation is not that bad here." One key officer indicated:

"...though lecturers salary is improving I can say that they deserve far more than what they are taking.

The point here is that lecturers in the institution render critical skills which are not very common and

the salary I think must be made very attractive to prevent poaching of lecturers by the

universities". Similarly, another officer expressed, "somehow lecturers complains about salaries

a lot which means they are still not satisfied and frankly am not satisfied either".

In essence, the respondents admitted that in comparison with what teaching staff members in other public universities receive, their situation is not the best and should be addressed for the institution to be able to attract high caliber professionals. It is noteworthy that salary level in the institution is poor compared with what teaching staff from other public universities and other establishments are receiving. This finding is in agreement with that of Rebore (2007) which suggested that the best people for a job will become candidates if the financial compensation is in keeping with the responsibilities of their position. HR capacities are influenced by economic, physical, psychosocial and skill related other factors. If these factors are lacking then the HR capacities are likely to be affected adversely (Odoom, Kyeremh and Opoku, 2014; Wood, 2000; World Bank, 2005). In their study on teacher motivation and performance in Ghana, Odoom, Opoku and Ayipah (2016b) found that higher salary is positively correlated with increased teachers' performance and vice versa. The authors discovered that salaries of teachers in Ghana very low compared with what colleagues with similar qualifications receive in other establishments. 


\begin{tabular}{|c|c|c|c|c|c|c|c|c|c|c|}
\hline $\begin{array}{c}\text { Challenges to Recruitment and } \\
\text { Selection }\end{array}$ & \multicolumn{2}{|c|}{$\begin{array}{c}\text { Strongly } \\
\text { Agree }\end{array}$} & \multicolumn{2}{|c|}{ Agree } & \multicolumn{2}{c|}{ Disagree } & \multicolumn{2}{c|}{$\begin{array}{c}\text { Strongly } \\
\text { Disagree }\end{array}$} & \multicolumn{2}{c|}{ Undecided } \\
\cline { 2 - 11 } & No. & $\%$ & No. & $\%$ & No. & $\%$ & No. & $\%$ & No. & $\%$ \\
\hline $\begin{array}{c}\text { Poor salary as compared with } \\
\text { other tertiary institutions }\end{array}$ & 34 & 37 & 47 & 51.1 & 6 & 6.5 & 5 & 5.4 & 0 & 0 \\
\hline $\begin{array}{c}\text { Competition from other tertiary } \\
\text { institutions over quality personnel }\end{array}$ & 31 & 33.7 & 42 & 45.7 & 11 & 12 & 5 & 5.4 & 3 & 3.2 \\
\hline $\begin{array}{c}\text { Insufficient autonomy to carry out } \\
\text { recruitment and selection }\end{array}$ & 34 & 37 & 45 & 48.9 & 6 & 6.5 & 5 & 5.4 & 2 & 2.2 \\
\hline $\begin{array}{c}\text { Vacant positions not declared and } \\
\text { filled on time }\end{array}$ & 34 & 37 & 47 & 51.1 & 6 & 6.5 & 5 & 5.4 & 0 & 0 \\
\hline $\begin{array}{c}\text { Too much favoritism and personal } \\
\text { contact hinders recruitment and } \\
\text { selection process }\end{array}$ & 24 & 26.1 & 44 & 47.8 & 9 & 9.8 & 13 & 14.1 & 2 & 2.2 \\
\hline $\begin{array}{c}\text { Over-reliance on internal } \\
\text { recruitment and selection method }\end{array}$ & 14 & 15.2 & 37 & 40.2 & 26 & 28.3 & 12 & 13.0 & 3 & 3.3 \\
\hline $\begin{array}{c}\text { Political influencein the } \\
\text { recruitment process }\end{array}$ & 27 & 29.4 & 41 & 44.6 & 13 & 14.1 & 6 & 6.5 & 5 & 5.4 \\
\hline $\begin{array}{c}\text { Inadequate incentive packages in } \\
\text { the institution as compared with } \\
\text { other public universities }\end{array}$ & 34 & 37 & 45 & 48.9 & 6 & 6.5 & 5 & 5.4 & 2 & 2.2 \\
\hline $\begin{array}{c}\text { Bad image of Takoradi Technical } \\
\text { University }\end{array}$ & 7 & 7.6 & 5 & 5.4 & 26 & 28.3 & 47 & 51.1 & 7 & 7.6 \\
\hline $\begin{array}{c}\text { Very large pool of qualified } \\
\text { applicants making staff selection } \\
\text { difficult }\end{array}$ & 30 & 32.6 & 37 & 40.2 & 6 & 6.5 & 15 & 16.3 & 4 & 4.4 \\
\hline Some positions are anxiety-laden & 17 & 18.5 & 34 & 37 & 13 & 14.1 & 22 & 23.9 & 6 & 6.5 \\
\hline
\end{tabular}

Table 2: Challenges to Recruitment and Selection

Source: Field Survey, 2016

Closely following the above is the issue of competition from other tertiary institutions over quality personnel. The results in Table 2 show that there is too much competition from other tertiary institutions over well-qualified personnel. For instance, 79.4 percent of the respondents stated that the University finds it very difficult to compete with other universities and establishments over high caliber personnel whereas 17.4 percent generally disagreed. Indeed, the view held by the majority who respondents to the question was also corroborated by the key informants. During the interview, it was revealed that there was a serious competition from other universities and establishments over high caliber personnel. One key informant said, "In fact the competition is too much. UCC, Legon, KNUST and UMaT are all competing with us over the high caliber personnel. There is also competition from GNPC, financial institutions and oil companies over personnel and you know these institutions pay their staff far better than the situation here." Another respondent commented, "The oil and mining companies are paying very high. They need these high caliber personnel to work with, so they easily get them. There are so many of such companies in the city, so it very challenging for us here." In essence, it is vivid based on the results from both approaches thatthe University's failure to compete favorably with other establishments including tertiary institutions, oil companies and banks is a major contributor to its recruitment challenges. This finding does not depart from that of Afeti (2003). Afeti (2003) opines that the very qualified personnel needed in the polytechnics are those who are highly sought after by other institutions. Gascard (2012) extends the debate by indicating that such competition particularly hits fields such as medicine, technology and engineering, where tertiary institutions cannot compete with the private sector in terms of payment of salaries and other incentives.

Moreover, the study found that there was insufficient autonomy of the University in addressing its HR issues including recruitment and selection. It is evident from Table 2 that while 85.9 percent generally indicated that it insufficient autonomy was a challenge to recruitment, 11.9 percent held a contrary view. Nonetheless, it is obvious that the majority (85.9\%) of the respondents believed that the institution did not have sufficient autonomy to deal with its recruitment and selection issues. Again, interviews with the key informants revealed that for some time the institution had wanted to employ more persons to complement the existing staff strength but could not do so due to government restrictions. One informant commented, "If government has not given us clearance, there is no way we can recruit especially permanent personnel, no matter the situation. The best we can do is to hire part time employees." In merging the results from the two approaches, it should be noted that insufficient autonomy is partly blamed for the recruitment and selection challenges in the institution. The situation at TTU confirms the findings of Whit church and Gordon (2007) that the issue of insufficient autonomy at the tertiary institution hinders their efforts at carrying out HR operations including recruitment and selection. This finding also resonates with that of Kwaw (2015) who discovered that due to insufficient autonomy the Cape Coast Technical University was unable to properly deal with its HR challenges.

Additionally, recruitment challenge that was found in institution is the issue of favoritism and personal contact during recruitment and selection of applicants. It is lucid from Table 2 that while 73.9 percent of the respondents believed that favoritism and personal contact was a challenge to the success of recruitment and selection process at the University, 
23.9 percent held a different position. This implies that most (73.9\%) of the respondents were of the view that recruitment and selection process at the institution was bedeviled with too much favoritism and personal contact. During the interviews, while some of the key informants confirmed that favoritism and personal contact played a role in determining how persons are recruited and selected into the institution others vehemently denied it. However, it is noteworthy from the results that favoritism and personal contact had been a challenge to the University's recruitment and selection process. This finding sits well with that of Gascard (2012) who discovered that personal connections sometimes play a crucial part in recruitment and selection of staff of tertiary institutions. Gascard further cautions that the situation potentially hinders the development of tertiary institutions since they may be denied adequate and well-qualified staff for goal attainment. The present study further highlights the concern raised by Kwaw (2015) in her study. Kwaw found that an appalling situation exists in places such as the Cape Coast Technical University where recruitment and selection process was largely influenced by favoritism and personal connection.

Besides, political influence was identified as a challenge in the way of recruitment process of the institution. From Table 2, it is clear that as high as 74 percent of the respondents saw political interference as a challenge to the success of recruitment and selection. By implication, the majority (74\%) of the respondents held the view that political influence hinders the effectiveness of the recruitment and selection process of the institution. However, during the interviews the key informants entirely rejected the claim that political influence hampered the success of the University's recruitment and selection process. One informant remarked, "Oh no, we are professionals and so we do not allow politicians to tell us how and who should be recruited into the institution." Another informant said, "Sometimes political influence from both within and outside the institutions try to push their interests but the situation is under control. We will not allow political forces to determine how we should go about our recruitment and selection exercise." Despite their contrary view, the key informants admitted that politicians both in government and in opposition occasionally try to see if they could push their people through during recruitment and selection exercise. Thus, from the two approaches, the issue of political influence should not be taken for granted in all this. It is therefore fair to indicate that political influence potentially could account for the challenges the University is faced with in terms of recruitment and selection of qualified personnel. As a process, recruitment also entails discovering potential applicants for anticipated vacancies (Gerber et al., 1998); thus the process of recruitment must be fair without interference. Political influence during recruitment and selection process results in lack of open competition for positions in senior management such as deans and rectors. They are often politicized in their selection or appointment coupled with lack of adequate and transparent selection criteria (Gascard, 2012; Kwaw, 2015).

Furthermore, the situation where vacant positions were not declared and filled on time was seen as a challenge to recruitment and selection. In support, 88.1 percent of the respondents said that vacant positions not declared and filled on time whilst 11.9 percent generally disagreed. This shows that the majority $(88.1 \%)$ of the respondents saw delay in declaring and filling vacant positions as a challenge to recruitment and selection process. During the interview, the key informants all admitted that the University sometimes delays in declaring and filling vacant positions. They however attributed the situation to the fact that if government has not given them the "go-ahead" they cannot declare and fill vacant positions. One informant said, "Yes it is true we delay in declaring and filling vacant positions. But it due to the powers that be. If they give us clearance then we go ahead with recruitment and selection. If they have not given us the "go ahead" we do not recruit people." From both the quantitative and qualitative approaches, it is succinct that delays in declaring and filling vacant positions contributed to the recruitment and selection challenges faced by the institution.

Other recruitment and selection challenges found in this study include inadequate incentive packages in the institution as compared with other public universities; over-reliance on internal recruitment; very large pool of qualified applicants making staff selection difficult; and the fact that some positions were anxiety-laden. All these challenges were also identified by the key informants. For instance, one key informant said that getting good accommodation for their Lecturers has been a major concern since the University does not have enough money to meet the increasingly high rents charged by landlords and landladies in the city. The finding on accommodations corroborates Nyarko's (2011) position that inadequate accommodation is a major challenge in most of the polytechnics in Ghana. Also, over-relying on internal recruitment may be viewed in terms of promoting persons to occupy positions such as head of department, head of units or sections, dean and registrar. Indeed, in the view of Rebore (2007) educational institutions often over-rely on internal recruitment procedure when it comes to tackling their HR needs as a strategy to ensure high morale among employees. However, Rebore bemoans that the situation can also derail efforts at getting quality personnel. Over-reliance on internal recruitment strategy results in employing mediocre personnel at the expense of highly qualified candidates who are outside the institution (Kwaw, 2015; Rebore, 2007). There is also the possible danger of inbreeding. Beyond this, this study supports Kwaw (2015) who found that tertiary institutions in Ghana including the Cape Coast Technical University tend to over-rely on internal recruitment procedure.

\subsection{Testing of Hypotheses}

The hypotheses were tested using an independent sample t-test analysis at 0.05 level of significance. According to the rule in hypothesis testing, the null hypothesis is rejected when the p-value is less than the alpha value which is set at 0.05 (i.e. $\mathrm{p}<0.05$ ). Thus, the result is statistically significant or the variances are significantly different. On the other hand, the null hypothesis is not rejected when the $p$ value is greater than the alpha value (ie. $p>0.05$ ), meaning the result is not statistically significant or the variances are not significantly different. Tables 3 and 4 respectively show the group statistics and independent samples test used in determining the difference recruitment and selection challenges in relation to the gender of lecturers. The mean scores in Table 3 for the male lecturers $(m=30.93)$ is higher than the female lecturers $(\mathrm{m}=29.89)$. A further analysis of the data with an independent $\mathrm{t}$-test (Table 4) indicates that the $\mathrm{p}$-value of the Levene's 
Test (.296) is greater than the level of significance (0.05), therefore equal variances are assumed. The Sig. (2-tailed) value of assumed equal variance (.157) is greater than 0.05 , meaning the result is not statistically significant.

\begin{tabular}{|c|c|c|c|c|c|}
\hline & Sex of Respondents & $\mathbf{N}$ & Mean & Std. Deviation & Std. Error Mean \\
\hline \multirow{2}{*}{$\begin{array}{c}\text { Recruitment and Selection } \\
\text { Challenges }\end{array}$} & Male & 57 & 30.93 & 3.644 & .483 \\
\cline { 2 - 6 } & Female & 35 & 29.89 & 2.968 & .502 \\
\hline
\end{tabular}

Table 3: Group Statistics of Gender and Recruitment Challenges

Source: Field Survey, 2016

Thus, the null hypothesis which states that there is no statistically significant difference in recruitment and selection challenges according to the gender of lecturers is not rejected. This indicates that the recruitment and selection challenges that male lecturers face are not different from that of their female colleagues.

\begin{tabular}{|c|c|c|c|c|c|c|c|}
\hline & \multicolumn{2}{|c|}{$\begin{array}{c}\text { Levene's Test for } \\
\text { Equality of Variances }\end{array}$} & \multicolumn{5}{|c|}{ t-test for Equality of Means } \\
\hline & $\mathrm{F}$ & Sig. & $\mathrm{T}$ & $\mathrm{df}$ & $\begin{array}{c}\text { Sig. } \\
\text { (2-tailed) }\end{array}$ & Mean Diff. & $\begin{array}{c}\text { Std. Error } \\
\text { Diff. }\end{array}$ \\
\hline $\begin{array}{c}\text { Equal variances } \\
\text { assumed }\end{array}$ & 1.11 & .296 & 1.43 & 90 & .157 & 2.43 & .73 \\
\hline $\begin{array}{c}\text { Equal variances not } \\
\text { assumed }\end{array}$ & & & 1.50 & 82.93 & .137 & 1.04 & .69 \\
\hline
\end{tabular}

Table 4: An Independent Sample Test of Gender and Recruitment and Selection Challenges

Source: Field Survey, 2016

\section{Conclusions and Recommendations}

Governments play a major role in the recruitment of teaching staff in the various public tertiary institutions including the technical universities in the country. This is mainly because public tertiary institutions are governmentfunded. Besides, the government is the single largest employer in the country. In essence, until the government lifts the embargo on recruitment, all attempts and processes by the technical universities' authorities to recruit staff to lectureship positions will be less productive. Moreover, adequate salary is crucial in enhancing recruitments in the tertiary institutions. Besides, unattractive and uninspiring fringe benefits for lecturers hamper effective recruitment of teaching staff in places such as the Takoradi Technical University. Also, the recruitment challenges that male lecturers face Takoradi Technical University are not different from that of their female colleagues. It is recommended that government should put in place clear measures to facilitate the employment of persons to teach in the tertiary institutions including removing embargos and also giving the necessary clearance on time. This would not only increase the academic workforce of the institution but also reduce the workload on the current workforce. The authorities of Takoradi Technical University and the HRM Division should team up and come out with clear strategies to attract and retain well-qualified professionals for the growth and development of the institution. Thus, a focus on gender in addressing these challenges may not yield any significant outcomes.

\section{References}

i. Acheampong, I. K. (2006). Human resource development: Labour market concepts and operations. Cape Coast: Catholic Mission Press.

ii. Adesina, S. (1990). Educational management. Enugu, Nigeria: Fourth Dimension Publishing Co. Ltd.

iii. Afeti, G. (2003). Promoting change and innovation in tertiary education: Experience of Ho Polytechnic. Accra: Ho Polytechnic.

iv. Analoui, F. (2007). Strategic human resource management. U.K: Thomson Learning.

v. Armstrong, M. (2006). A handbook of human resource management practice (10 th ed.). London: Cambridge University Press.

vi. Azzani, E., \& Kennedy, M. (2008). Workplace unfairness: Combating subtle discrimination. Retrieved from:http:/ / diversity executive.com/ article.php? article=328

vii. Ballantyne, I. (2009). Recruiting and selecting staff in organizations. Oxford: Oxford University Press.

viii. Bratton, J., and Gold, J. (2007). Human resource management: Theory and practice (4th ed.).

Houndmills: Macmillan.

ix. Beauregard, M. and Fitzgerald, M. (2000). Hiring, managing and keeping the best: The complete Canadian guide for employers. Journal of Cooperative Education and Internship, 36(1), 48-60.

x. Carol, B. (2008). Outcome realisation and organisational change management.Psychological Science, 21 (3), 1-49.

xi. Chaminade, B. (2007). A retention checklist: how do you rate? Retrieved from:

xii. http:/ / www.humanresourcesmagazine.co.au.

xiii. Chan T. (2002). Knowledge management in document company in capitalising on knowledge workers. Tokyo: APO.

xiv. Chew, J. C. (2004). The influence of human resource management practices on the retention of core employees of Australian Organisations: An unpublished doctoral thesis, Murdoch University, Perth. 
xv. Chew, J. C. (2004). The influence of human resource management practices on the retention of core employees of Australian Organisations: An unpublished doctoral thesis, Murdoch University, Perth.

xvi. Cole, G. A. (1996). Management theory and practice. Guemsey: The Guemsey Press.

xvii. Cole, G. A. (2004). Management theory and practice. U.K: Thomson Learning.

xviii. Gascard, G. (2012). Human resource management in public higher education in the Tempus Partner Countries.Retrieved from: http:/ / eacea.earopa.eu/ tempus.

xix. Ghana Government (2007). Polytechnic Law. Accra: Ministry of Education.

xx. Gomez-Mejia, L. R., Balkin, D. B. and Cardy, R. L. (2007). Managing human resources. New Jersey: Pearson Education Inc.

xxi. Government of Ghana (2007). Polytechnic Law 745. Accra: Ministry of Education.

xxii. Government of Ghana (2014). Report of the technical committee on conversion of polytechnics in Ghana to technical universities. Accra: Ministry of Education.

xxiii. Harbison, F. H. (1973). Human resources as the wealth of nations. London; Oxford University Press Inc.

xxiv. Harris, A. (2009). Big change question: Does politics help or hinder educational change? Journal of Educational Change, 10, 63-67.

xxv. Haslinda, A. (2009). Evolving terms of human resource management. Harlow: Pearson Education Limited.

xxvi. Honyenuga, B. Q. (2013). Polytechnic education in Ghana: A change management perspective. International Journal of Social Science \& Interdisciplinary Research, 2 (1).

xxvii. Kwaw, J. (2015). Staff perception on human resource management challenges and strategies at the Cape Coast Polytechnic. An unpublished master's thesis, University of Cape Coast, Cape Coast.

xxviii. National Accreditation Board (2008). Retrieved from: http:/ / www.nab.gov.gh/

xxix. NCTE (2001). Report on technical committee on polytechnic education in Ghana. Accra: Adwinsa Publications.

xxx. Nwana, O. C. (1992). Introduction to educational research for student-teachers: Designing the study. Nigeria: Heineman Educational Books (Nig.) PLC.

xxxi. Nyarko, D. A. (2011). Polytechnic education in Ghana: The challenges and the prospect. Retrieved from: http;// www.esjournals.org

xxxii. Odoom, D., Opoku, E. and Ayipah-Ntiakoh, D. (2017). Exploring the Staff Development Challenges and Strategies at Agogo College of Education, Ghana. International Journal of Innovative Research and Development, 6(2), 78-92.

xxxiii. Odoom, D., Opoku, E. and Ayipah-Ntiakoh, D. (2016a). Staff development needs at the Colleges of Education in Ghana: Evidence from the Agogo College. International Journal of Innovative Research and Development, 5(1), 127137.

xxxiv. Odoom, D., Opoku, E. and Ayipah-Ntiakoh, D. (2016b). Teacher motivation and performance: The case of some selected Early Childhood Care and Education Centres in the Cape Coast Metropolis of Ghana. International Journal of Innovative Research and Development, 5(1), 255-264.

xxxv. Odoom, D., Kyeremeh, C. and Opoku, E. (2014). Human resource capacity needs at the District Assemblies: A study at Assin South District in Ghana. Journal of Sustainable Development, 7(5), 177-188.

xxxvi. Plano Clark, V. L. and Creswell, J. W. (2015). Understanding research: A consumer's guide (2nd ed.). New Jersey: Pearson Education Inc

xxxvii. Rebore, R. W. (1982). Personnel administration in education. Englewood Cliff: Prentice Hall Inc.

xxxviii. Rebore, R. W (2001). Human resource administration in education ( $6^{\text {th }}$ ed.). Needdham Heights: Allyn \& Bacon.

xxxix. Rebore, R. W. (2007). Human resource administration in education: A management approach (8th ed.). Boston: Pearson Education Inc.

xl. Sudhir, D. (2001). Human resources development (1 1 st ed.). New Delhi: Radha Publication.

xli. Wood, S. N. (2000). Building the human resources capacity of district Assemblies. Koforidua: MLGRD. 